Omni-Akuatika, 15 (2): 52-59, 2019
ISSN: 1858-3873 print / 2476-9347 online
Research Article
journal homepage: http://ojs.omniakuatika.net

\title{
Biological and Health Impact of Astaxanthin Powders in Common Carp Cyprinus carpio L.
}

\author{
Avan Aladin Sadraddin ${ }^{1, *}$, Bakhan Rafiq Hassan ${ }^{1}$, ShaimaSaleh Mahmood ${ }^{1}$, Nasreen \\ MohiAlddin Abdulrahman², Raber Mahmud Rashid ${ }^{1}$, KarzanNamiq $^{3}$ \\ ${ }^{1}$ College of Agricultural Engineering Science, University of Sulaimani, Iraq \\ ${ }^{2}$ College of Veterinary Medicine, University of Sulaimani, Iraq \\ ${ }^{3}$ Bakrajo Technical Institute, Sulaimani Polytechnic University, Iraq \\ ${ }^{*}$ Corresponding author: karzan.namiq@spu.edu.iq
}

Received 9 October 2019; Accepted 26 October 2019; Available online 28 November 2019

\begin{abstract}
The effect of Astaxanthin powders on biological, health and growth parameter of common carp Cyprinus carpio L. Fish weight varied between $(59.2-66.4 \mathrm{~g})$ were studied for 10 weeks. Four treatments (triplicate) were employed as follows: T1: Diet without any addition, T2: adding $2.5 \mathrm{~g}$ Astaxanthin powders $/ \mathrm{kg}$ diet, T3: adding $5 \mathrm{~g}$ Astaxanthin powders $/ \mathrm{kg}$ diet, T4: adding $7.5 \mathrm{~g}$ Astaxanthin powders $/ \mathrm{kg}$ diet. Twice daily feeding at 9:00 a.m. and 2:00 p.m. Blood samples were taken from the caudal vein of fish. The results showed no significant difference between treatments in terms of biological parameter $(p>0.05)$. The results showed a significant difference between treatments in terms of Health indices, including gonadosomatic, but no significant difference $(p>0.05)$ hepatosomatic, spleenosomatic index and Gill index. The results showed a significant difference between treatments in terms of growth performance $(p<0.05)$, including weight gain, Relative growth rate and Specific growth rate. Group results of blood factors showed that between Granulocytes, Lymphocytes and Monocytes there was no significant difference between treatments $(p>0.05)$. Lastly, we found that diets containing higher levels of astaxanthin powders improve the growth performance, biological and GSI in common carp Cyprinus carpio L.
\end{abstract}

Keywords: common carp Cyprinus carpio L., Astaxanthin powders, Biological and Health parameter and growth performance.

\begin{abstract}
ABSTRAK
Efek Astaxanthin bubuk pada biologis, kesehatan dan pertumbuhan parameter Ikan Mas Cyprinus carpio L. Berat ikan variasi antara $(59.2$ - 66.4 GM) dipelajari selama 10 minggu. Empat perlakuan (tiga replikasi) yang digunakan sebagai berikut: T1: diet tanpa penambahan, T2: ditambahkan $2.5 \mathrm{gr}$ bubuk Astaxanthin $/ \mathrm{kg}$ diet, T3: ditambahkan $5 \mathrm{~g}$ bubuk Astaxanthin $/ \mathrm{kg}$ diet, T4: ditambahkan $7.5 \mathrm{~g}$ bubuk Astaxanthin $/ \mathrm{kg}$ diet. Pemberian pakan dilakukan pada 9:00 a.m dan 2:00 p.m. Sampel darah diambil dari vena caudal ikan. Hasilnya menunjukkan tidak ada perbedaan yang signifikan antar perlakuan dalam hal parameter biologis $(p>0.05)$. Hasilnya menunjukkan perbedaan yang signifikan antara perawatan dalam hal Indeks Kesehatan, termasuk gonadosomatik, tetapi tidak ada perbedaan yang signifikan ( $p>0.05)$ hepatosomatic, indeks spleenosomatic dan indeks Gill. Hasilnya menunjukkan perbedaan yang signifikan antara perawatan dalam hal kinerja pertumbuhan $(p<0.05)$, termasuk penambahan berat badan, tingkat pertumbuhan relatif dan tingkat pertumbuhan spesifik. Hasil pengelompokan faktor darah menunjukkan bahwa antara Granulosit, Limfosit dan Monosit tidak memiliki perbedaan yang signifikan antar perlakuan ( $p>0.05)$. Terakhir, kami menemukan bahwa diet yang mengandung tingkat yang lebih tinggi dari bubuk Astaxanthin
\end{abstract}


meningkatkan kinerja pertumbuhan, biologis dan Gonadosomatic index \% (GSI) yang umumnya digunaan untuk Cyprinus carpio L.

Kata Kunci: ikan mas Cyprinus carpio L., serbuk Astaxanthin, parameter biologis, kesehatan dan kinerja pertumbuhan.

\section{Introduction}

Numerous studies have shown that astaxanthin has potential health-promoting effects in the prevention and treatment of various diseases, such as cancers, chronic inflammatory diseases, metabolic syndrome, diabetes, diabetic nephropathy, cardiovascular diseases, gastrointestinal diseases, liver diseases, neurodegenerative diseases, eye diseases, skin diseases, exercise-induced fatigue, male infertility as reviewed by Yuan et al. (2010). It has been proven in over 65 clinical studies, featured in over 300 peer-reviewed publications. The main benefits for human health. "Eye fatigue relieve" (Yamashita, 2009), "skin aging defence" (anti-photoaging) (Tominaga et al., 2012) and "muscle resilience" (sports performance enhancement) (Yamashita, 2011; Earnest et al., 2011) have been most clinically substantiated.

The natural sources of astaxanthin are algae, yeast, salmon, trout, krill, shrimp and crayfish. Astaxanthin from various microorganism sources. The commercial astaxanthin is mainly from Phaffia yeast, Haematococcus and through chemical synthesis. Haematococcus pluvialis is one of the best sources of natural astaxanthin (Ranga Rao et al., 2010).

Carotenoids are pigments found in plants and animals, but only plants, including algae, some bacteria and yeasts are able to produce them. Nonetheless, structural variants of carotenoids can still be found in animals. Perciformes and Salmonidae fish synthesize zeaxanthin from astaxanthin; however, this is reversed in Cyprinidae fish, with astaxanthin being synthesized from zeaxanthin (Maoka, 2011). Research has shown that carp fed high-carotenoid diets retained serum astaxanthin and red color better than did other groups and had a higher phagocyte concentration (Yuangsoi et al., 2010). It has been shown that astaxanthin and $\beta$-carotene improves the reproductive performance and egg quality of female goldfish (Tizkar et al., 2013).
Some microorganisms are rich in
astaxanthin - the Chlorophyte
Haematococcus pluvialis is a green
microalga, which accumulates high astaxanthin content under stress conditions such as high salinity, nitrogen deficiency, high temperature and light (Sarada et al., 2012). Astaxanthin is closely related to other well-known carotenoids, such as b-carotene, zeaxanthin and lutein, thus they share many of the metabolic and physiological functions attributed to carotenoids. Free astaxanthin is particularly sensitive to oxidation. In nature, it is found either conjugated to proteins, such as in salmon muscle or lobster exoskeleton, or esterified with one or two fatty acids, which stabilize the molecule. Astaxanthin in $\mathrm{H}$. pluvialis offered the best protection from free radicals in rats followed by $\beta$-carotene and lutein (Ranga Rao et al., 2013; Ranga Rao et al., 2010).

Astaxanthin contains a unique molecular structure in the presence of hydroxyl and keto moieties on each ionone ring, which are responsible for the high antioxidant properties (Kidd, 2011). Astaxanthin cannot be synthesized by animals and must be acquired from the diet. Although mammals and most fish are unable to convert other dietary carotenoids into astaxanthin, crustaceans (such as shrimp and some fish species including koi carp) have a limited capacity to convert closely related dietary carotenoids into astaxanthin, although they benefit from being fed astaxanthin directly. The consumption of astaxanthin can prevent or reduce risk of various disorders in humans and animals (Kidd, 2011).

The use of astaxanthin as a nutritional supplement has been rapidly growing in foods, feeds, nutraceuticals and pharmaceuticals. This present review paper provides information on astaxanthin sources, extraction methods, storage stability, biological activities, and health benefits for the prevention of various diseases and use in commercial applications, based on the benefits of Astaxanthin the present experiment will dome to assess their effects 
in some biological and Health indices in common carp Cyprinus carpio L.

\section{Materials and Methods}

\subsection{Experimental fish}

The experiment will be done 10 weeks on 60 common carp C. carpio L. brought from local fish ponds in Daquq/ Kirkuk/ Iraq. Fish weight varied between $(59.2-66.4 \mathrm{gm})$. Fish distributed among experimental plastic tanks with mean initial weight $61.45 \mathrm{gm}$. laboratory pre-acclimation and feeding with commercial pellets (their Percentage of ingredients and chemical composition are seen in Table 1 and 2) were for 21 days prior to the real feeding trials.

\subsection{Experimental system}

Twelve plastic tanks (70 L water) will be used in this trial for four treatments each with three replicates. Proper continuous aeration added to each tank by using Chinese's air compressors, Hailea ACO-318. Each replicate was stocked with six fish. The replicates will be randomly placed to reduced differences among treatments. A daily cleaning by siphoning method will be applied to remove remained feeds and feces from the system. the experimental trial represent four treatments with three replicates; each with five fish per replicate as bellow: T1: Diet without any adiition, T2: adding $2.5 \mathrm{gm}$ Astaxanthin powder $/ \mathrm{kg}$ diet, T3: adding $5 \mathrm{gm}$ Astaxanthin powder $/ \mathrm{kg}$ diet, T4: adding $7.5 \mathrm{gm}$ Astaxanthin powder $/ \mathrm{kg}$ diet.

\subsection{Diet formulation \\ Experimental diets contain standard} ingredients found in Sulaimani city markets, enriched with Astaxanthin powder. The items will be mixed to obtain dough. Then, using electrical mincer for pelleting by Kenwood Multi-processors. Room temperature drying used for a four days and crushed to obtained fine particles. Twice daily feeding at 9:00 a.m. and 2:00 p.m. with $3 \%$ of body weight. Fish in every tank will be weighed together bimonthly. The feeding levels will be then recalculated according to new weights. The feeding trial continued for 10 weeks.

\subsection{Health and biological parameters}

All fish specimens will be dissected and the abdominal cavity will opened to weigh each organ alone.

\subsection{Growth standards used in the study}

Fish weighed $(\mathrm{g})$ together for all replicate every two weeks. Feed consumption of each replicate will be read just by the obtained biomass at every two weeks.

\subsection{Statistical analysis}

The trial will be conducted by one way (ANOVA) with completely randomized design (CRD) and general linear models (GLM) procedure of XLSTAT 2016 Version.02.28451. Duncan's test will used to compare among treatments means.

Table 1. Chemical composition of the different diet by NRC (1993)

\begin{tabular}{lccccc}
\hline \multicolumn{1}{c}{ Ingredients } & $\begin{array}{c}\text { Crude Protein } \\
\%\end{array}$ & $\begin{array}{c}\text { Crude Fat } \\
\%\end{array}$ & $\begin{array}{c}\text { Dry Matter } \\
\%\end{array}$ & $\begin{array}{c}\text { Crude Fiber } \\
\%\end{array}$ & $\begin{array}{c}\text { Energy } \\
\text { Kcal/ kg }\end{array}$ \\
\hline .Animal protein & & & & & \\
Concentrate & 40 & 5 & 92.9 & 2.2 & 2107 \\
.Yellow corn & 8.9 & 3.6 & 89 & 2.2 & 3400 \\
.Soybean meal & 48 & 1.1 & 89 & 7 & 2230 \\
Barely & 11 & 1.9 & 89 & 5.5 & 2640 \\
.Wheat bran & 15.7 & 4 & 89 & 11 & 1300 \\
\hline
\end{tabular}

Table 2. Composition of experimental diet

\begin{tabular}{lc}
\hline Ingredients & Percent (\%) \\
\hline Yellow corn & $15 \%$ \\
Wheat bran & $15 \%$ \\
Animal concentrate protein & $20 \%$ \\
Barley & $15 \%$ \\
Soya bean meal 48\% & $35 \%$ \\
Total & \\
Crud protein & 28.06 \\
Gross energy (kcal/kg feed) & 2242.7 \\
\hline
\end{tabular}




\section{Results and Discussion}

\subsection{Biological parameters}

Biological performance: Fish fed T2 (2.5gm astaxanthin powder), T3 (5 gm Astaxanthin powder) and T4 (7.5gm Astaxanthin powder) achieved higher Intestine weight index $\%$ and Intestine length index\% compared to the CON without significant differences $(P>0.05)$ (Table 2), There were no significant differences among treatments in the Condition factor. Also, condition factor did not show any significant differences among studied groups, and no specific signs of disease were observed $(P>0.05)$. Meat weight index $\%$ and Fish weight index\% ( $P>0.05)$ (Table 2). All groups fed with astaxanthin powder diets had better feed performance compared to the CON.

\subsection{Health parameter}

Data on some Body indices are shown in (Table 4). No significant $(p>0.05)$ differences were recorded in HIS, SSI and GI (\%). The T3 (5gm astaxanthin powder $/ \mathrm{kg}$ ) had a significantly higher GSI than fish fed the CON $(P<0.05)$.

\subsection{Blood parameter}

In this experiment, blood factors including Granulocytes \%, Lymphocytes \% and Monocytes \% there was no significant difference between treatments $(p>0.05)$ (Table 5).

\subsection{Growth performances}

Growth data of the Growth rate (GR) in fish fed the T2, T3, and T4 diets was comparable with the CON $(P>0.05)$ (Table 6). However, fish fed the T4 (7.5gm Astaxanthin

Table 3. Effect of adding astaxanthin powder in some biological parameters

\begin{tabular}{lllll}
\hline \multirow{2}{*}{ Parameter } & \multicolumn{4}{c}{ Dietary treatment } \\
\cline { 2 - 5 } & \multicolumn{1}{c}{$\begin{array}{c}\text { T1 Control } \\
(\text { con })\end{array}$} & $\begin{array}{c}\text { T2 }(2.5 \mathrm{gm}) \\
\text { Astaxanthin } \\
\text { powder } / \mathrm{kg}\end{array}$ & $\begin{array}{c}\text { T3(5gm) } \\
\text { Astaxanthin } \\
\text { powder } / \mathrm{kg}\end{array}$ & $\begin{array}{c}\text { T4 (7.5gm) } \\
\text { Astaxanthin } \\
\text { powder } / \mathrm{kg}\end{array}$ \\
\hline Intestine weight index \% & $2.106^{\mathrm{a}} \pm 0.586$ & $2.415^{\mathrm{a}} \pm 0.326$ & $2.197^{\mathrm{a}} \pm 0.108$ & $2.523^{\mathrm{a}} \pm 0.308$ \\
Intestine length index \% & $26.551^{\mathrm{a}} \pm 0.425$ & $29.173^{\mathrm{a}} \pm 0.775$ & $34.080^{\mathrm{a}} \pm 1.224$ & $30.613^{\mathrm{a}} \pm 1.200$ \\
Condition factor (CF) & $1.410^{\mathrm{a}} \pm 0.302$ & $1.552^{\mathrm{a}} \pm 0.886$ & $1.555^{\mathrm{a}} \pm 0.273$ & $1.456^{\mathrm{a}} \pm 0.857$ \\
Meat weight index \% & $50.723^{\mathrm{a}} \pm 0.611$ & $53.068^{\mathrm{a}} \pm 0.348$ & $54.134^{\mathrm{a}} \pm 0.263$ & $55.542^{\mathrm{a}} \pm 0.842$ \\
Fish weight index \% & $82.519^{\mathrm{a}} \pm 0.133$ & $87.043^{\mathrm{a}} \pm 0.383$ & $85.317^{\mathrm{a}} \pm 0.656$ & $87.957^{\mathrm{a}} \pm 0.789$ \\
\hline
\end{tabular}

* Values are listed as mean \pm SD ( $n=3$ in each group)

* Comparisons of means (control and treated fish) Significant at $5 \%$ level $(p<0.05)$. *Con, control diet $* T$, treatment and CF, Condition factor

* Intestine weight index $\%=$ Intestine weight $(\mathrm{gm}) /$ Fish weight $(\mathrm{gm}) \times 100$

* Intestine length index \% = Intestine length (gm) / Fish length $(\mathrm{gm}) \times 100$

* Condition factor $=$ Fish weight $(\mathrm{gm}) /$ Fish length $(\mathrm{cm})^{3}$

* Meat weight index $\%=$ Fish weight without Viscera \& Head $(\mathrm{gm}) /$ Fish weight $(\mathrm{gm}) \times 100$

* Fish weight index \% = Fish weight without Viscera (gm) / Fish weight $(\mathrm{gm}) \times 100$

Table 4. Effect of adding astaxanthin powder in some Body indices

\begin{tabular}{lcccc}
\hline \multirow{2}{*}{$\begin{array}{c}\text { Body } \\
\text { indices }\end{array}$} & $\begin{array}{c}\text { T1 Control } \\
\text { (con) }\end{array}$ & $\begin{array}{c}\text { T2 }(2.5 \mathrm{gm}) \\
\text { Astaxanthin } \\
\text { powder } / \mathrm{kg}\end{array}$ & $\begin{array}{c}\text { Dietary treatment } \\
\text { Astaxanthin } \\
\text { powder } / \mathrm{kg}\end{array}$ & $\begin{array}{c}\text { T4 (7.5gm) } \\
\text { Astaxanthin } \\
\text { powder } / \mathrm{kg}\end{array}$ \\
\hline $\mathrm{HIS} \%$ & $1.549^{\mathrm{a}} \pm 0.568$ & $1.706^{\mathrm{a}} \pm 0.801$ & $1.559^{\mathrm{a}} \pm 0.270$ & $1.780^{\mathrm{a}} \pm 0.838$ \\
$\mathrm{SSI} \%$ & $0.192^{\mathrm{a}} \pm 0.149$ & $0.439^{\mathrm{a}} \pm 0.879$ & $0.268^{\mathrm{a}} \pm 0.393$ & $0.239^{\mathrm{a}} \pm 0.244$ \\
$\mathrm{GI} \%$ & $3.643^{\mathrm{a}} \pm 0.160$ & $3.836^{\mathrm{a}} \pm 0.151$ & $3.685^{\mathrm{a}} \pm 0.117$ & $3.803^{\mathrm{a}} \pm 0.193$ \\
$\mathrm{GSI} \%$ & $0.555^{\mathrm{b}} \pm 0.673$ & $0.948^{\mathrm{ab}} \pm 0.886$ & $1.726^{\mathrm{a}} \pm 0.340$ & $0.702^{\mathrm{ab}} \pm 0.213$ \\
\hline
\end{tabular}

* Values are listed as mean \pm SD ( $n=3$ in each group), *Comparisons of means (control and treated fish) Significant at $5 \%$ level $(\mathrm{p}<0.05)$., *HIS, *Hepatosomatic index \%, *SSI, Spleenosomaticindex \%, *GI, Gill index \% and $* \mathrm{GSI}$, Gonadosomatic index \%

* Hepatosomatic index \% = Liver weight (gm) / Fish weight (gm) $\times 100$

* Spleenosomaticindex \% = Spleen weight (gm) / Fish weight (gm) $\times 100$

* Gonadosomatic index \% = Gonad weight $(\mathrm{gm}) /$ Fish weight $(\mathrm{gm}) \times 100, *$ Gill index $\%=$ Gill weight $(\mathrm{gm})$

/ Fish weight (gm) $\times 100$ 
Table 5. Effect of adding astaxanthin powder in some differential leukocyte count

\begin{tabular}{|c|c|c|c|c|}
\hline \multirow{3}{*}{$\begin{array}{l}\text { Leukocyte } \\
\text { Count }\end{array}$} & \multicolumn{4}{|c|}{ Dietary treatment } \\
\hline & \multirow[b]{2}{*}{ T1 control (con) } & T2 (2.5 gm) & T3 (5 gm) & T4 (7.5gm) \\
\hline & & $\begin{array}{l}\text { Astaxanthin } \\
\text { powder/kg }\end{array}$ & $\begin{array}{c}\text { Astaxanthin } \\
\text { powder } / \mathrm{kg}\end{array}$ & $\begin{array}{c}\text { Astaxanthin } \\
\text { powder } / \mathrm{kg}\end{array}$ \\
\hline Gran\% & $54.725 a \pm 0.950$ & $57.700 \mathrm{a} \pm 0.050$ & $56.250 a \pm 0.487$ & $57.550 a \pm 0.437$ \\
\hline Lym\% & $8.450 a \pm 0.219$ & $9.925 a \pm 0.992$ & $9.600 a \pm 0.471$ & $9.225 a \pm 0.774$ \\
\hline Mono\% & $33.225 a \pm 0.012$ & $33.850 a \pm 0.305$ & $35.675 a \pm 0.890$ & $33.825 a \pm 0.902$ \\
\hline \multicolumn{5}{|c|}{$\begin{array}{l}* \text { Values are listed as mean } \pm \text { SD }(n=3 \text { in each group), *Comparisons of means (control and } \\
\text { treated fish) Significant at } 5 \% \text { level }(p<0.05), \\
* \text { Gran } \% \text {, Granulocytes, } * \text { Lym } \%, \text { Lymphocytes and } * \text { Mono } \%, \text { Monocytes } \\
\text { Table } 6 . \text { Effect of adding astaxanthin powder in some Growth Performance }\end{array}$} \\
\hline \multirow[b]{2}{*}{ Parameter } & \multicolumn{4}{|c|}{ Dietary treatment } \\
\hline & $\begin{array}{l}\text { T1 Control } \\
\text { (con) }\end{array}$ & $\begin{array}{c}\text { T2 }(2.5 \mathrm{gm}) \\
\text { Astaxanthin } \\
\text { powder } / \mathrm{kg}\end{array}$ & $\begin{array}{c}\text { T3 }(5 \mathrm{gm}) \\
\text { Astaxanthin } \\
\text { powder } / \mathrm{kg}\end{array}$ & $\begin{array}{c}\text { T4 }(7.5 \mathrm{gm}) \\
\text { Astaxanthin } \\
\text { powder/kg }\end{array}$ \\
\hline WG & $7.173 \mathrm{~b} \pm 0.815$ & $7.507 \mathrm{~b} \pm 0.757$ & $10.987 \mathrm{ab} \pm 0.146$ & $11.820 \mathrm{a} \pm 0.748$ \\
\hline GR & $0.119 a \pm 0.016$ & $0.124 a \pm 0.005$ & $0.181 \mathrm{a} \pm 0.056$ & $0.197 a \pm 0.061$ \\
\hline RGR\% & $11.933 b \pm 0.058$ & $12.433 b \pm 0.657$ & $18.067 \mathrm{a} \pm 0.716$ & $19.700 a \pm 0.170$ \\
\hline SGR\% & $11.859 b \pm 0.089$ & $12.638 a b \pm 0.614$ & $17.998 \mathrm{a} \pm 0.703$ & $19.208 a \pm 0.124$ \\
\hline
\end{tabular}

powder $/ \mathrm{kg}$ ) and T3 (5 gm Astaxanthin powder $/ \mathrm{kg}$ ) achieved higher weight gain (WG), Relative growth rate (RGR\%) and specific growth rate (SGR\%) were significantly higher compared to the T2 $(2.5 \mathrm{gm}$ of astaxanthin powder $/ \mathrm{kg}$ ) and $\mathrm{CON}$ $(\mathrm{P}<0.05)$.

The biological and physiological condition of the fish is among the key factors underlying the attainment of the required performance levels. This is why monitoring the biological state of the common carp (Cyprinus carpio L.) has become an integral part of the routine examination of the health of the fish, and won a permanent position within the complex of methods serving to interpret the results of feeding trials, involved in the testing of the biological. For the carp (Cyprinus carpio L.). Li et al., (2014) reported that diets containing astaxanthin and Haematococcus pluvialis efficiently improved growth factors in large yellow croaker.

Shapoori et al., (2012) believe that the difference in the color intensity was caused by natural and artificial pigments are due to the quality, concentration, and the absorption period of these materials. Specifically, weight gain was significantly higher in fish fed with $H$. pluvialis than those fed with the diet containing astaxanthin. The present results show that astaxanthin powder can intervene, to a certain extent, with the biological and growth performance.

Carotenoids present in the diet, when consumed by fish, accumulate in the liver before being transferred to the ovaries in the late stages of maturity (Tizkar et al., 2013). Previous studies that examined the effects of carotenoid supplementation in rainbow trout, gilthead seabream and yellow tail cichlid broodstock (Lakeh et al., 2010; Scabini et al., 2010; Güroy et al., 2012) and carp (Tizkar et al., 2013) diets have been undertaken. Our results show that dietary supplementation of astaxanthin powder in common carp (Cyprinus carpio L.) Increased the GSI but did not affect the HSI. The pattern of carotenoid utilization between the gonads and the liver is in agreement with the results of similar studies with other fish (Sadekarpawar \& Parikh, 2013). The carotenoid enriched diets produced a positive effect on goldfish GSI and could lead to an increase in gonad weight brood stock (Chainapong \& Traichaiyaporn ,2013). The GSI and HSI indices are useful indicators of the effects of exposure to different substances, growth promoters and carotenoid in fish.

Considering the results of the leukocyte examination, we believe it is important to point out the significantly high levels of Granulocytes, Lymphocytes and 
Monocytes in the plasma of the fish fed the astanxanthin powder diet, however there was no significant difference between the groups fed astanxanthin powder and control in leukocyte count. Faghani et al., (2009) reported the level of Hct 21.1 \pm 0.65 , HB $5.23 \pm 0.64$ and Lym 82 \pm 5.1 . Generally, increased lysozyme activity in the serum and mucus of fish can be indicative of the immune system stimulation and improvement of the immune response. By enhancing the complement system and lysozyme, carotenoid pigments increase the total number of leukocytes and phagocytes and thereby cause the stimulation of the immune system, increased immunity, and resistance to pathogens. Wang et al., (2015) reported that dietary astaxanthin in Pacific white shrimp (Litopenaeus vannamei) significantly affects the hemolymph immunological index, including total haemocyte counts, phagocytic activity of haemocyte, serum anti-superoxide radical activity, serum phenoloxidase activity, serum antibacterial activity and serum bacteriolytic activity.

Astaxanthin are reported to improve growth performance of fish with the reason that carotenoids may exert a positive influence on intermediary metabolism in aquatic animals. There are different views about the effect of carotenoid pigments on growth factors of different fish species. While some results indicate that these pigments cannot improve growth factors in rainbow trout, Atlantic salmon, cod, Arctic char, and red porgy (Sheikhzadeh et al., 2012), the results of some other researchers suggest the positive effect of these pigments on growth improvement. This difference may be attributed to fish species, development stages, and type of carotenoid.

Kalinowski et al,. (2011) believed that astaxanthin powder could enhance lipid utilization in whole fish and liver, providing more energy and consequently enhancing growth performance. The relative growth rate was higher in the fish feed astaxanthin powder throughout the experiment. In addition, they might lead to negative effects on the taste of food, physical quality of the pellets and nutrition balance of diets (Lim, 1989). However, the degree of this effect naturally depends on the feeding habit of the fish and the preparation of the diet. Carp fish is herbivorous fish and, therefore, adding plants to their diets will be naturally restricted.
Based on the results, the highest growth was related to treatment $\mathrm{T} 4$ and $\mathrm{T} 3$ and respectively lowest treatments $\mathrm{T} 2$ and $\mathrm{T} 1$ that similar conditions were attributed together. Our results relating to the study of growth are similar to the conclusions published by (Foss et al.,1984). Who in trials with rainbow trout weighting $0.35 \mathrm{~kg}$, found no differences in growth rate when testing astaxanthin and canthaxanthin In the present experiment, the growth performance (WG, RGR and SGR) and feed utilization of fish fed diet with supplemental astaxanthin powder were significantly higher that of fish fed the control diet. However, effect of carotenoids on fish growth is controversial. Many earlier studies have reported that dietary astaxanthin has no significant influence on growth and flesh composition of fish (Zhang et al. 2012; Pham et al., 2014; Yi et al., 2014). Tukmechi et al., (2011) stated that some factors such as environmental factors, especially due to the coldness of the fish, seasons, salinity, photoperiod, temperature, density, physiological parameters, species, reproductive cycle, puberty status, age, gender, nutritional conditions, sampling time and method, and the accuracy and sensitivity of measurement methods can affect growth factors and survival and make a difference in the interpretation of researchers. Our results are also in keeping with the data of the growth trial conducted by (Rehulka and Zak, 1986).

\section{Conclusion}

In conclusion, treatments that fed with astaxanthin powder in terms of biological, health and growth parameter were in better condition than the control. According to the study, effective dose for the astaxanthin powder can be $7.5 \mathrm{gm} / \mathrm{kg}$. Due to the conditions of rearing, doses may be changed. astaxanthin in the diet for the common carp Cyprinus carpio L. Our results have again the justification of using the methods of clinical hematology and biochemistry within the complex of methods employed in assessing the biological and productive effectiveness of feeds.

\section{Acknowledgement}

The author would like to thank University of Sulaimany and college of 
engineer agriculture its Department of Animal Science, for their cooperation and assistance in this research.

\section{References}

Chainapong, T., Traichaiyaporn S. 2013. Enhancement of carotenoid production in Spirulina platensis and fed on Clarias macrocephalus for reproductive performance. International Journal of Agricultural Technology 9(1): 49-59.

Earnest, C.P., Lupo, M., White, K.M., Church, T.S. 2011. Effect of astaxanthin on cycling time trial performance. Int $\mathrm{J}$ Sports Med 32(11): 882-8.

Foss, P., Storebakken, T., Schiedt, K., Liaaen-Jensen, S., Austreng, E., Streiff, K. 1984. Carotenoids in diets for salmonids: I. Pigmentation of rainbow trout with the individual optical isomers of astaxanthin in comparison with canthaxanthin. Aquaculture 41(3): 213-226.

Güroy, B., Şahin, İ., Mantoğlu, S., Kayalı, Selin. 2012. Spirulina as a natural carotenoid source on growth, pigmentation and reproductive performance of yellow tail cichlid Pseudotropheus acei. Aquaculture International 20(5): 869-878.

Li, M., Wu, W., Zhou, P., Xie, F., Zhou, Q., Mai, K. 2014. Comparison effect of dietary astaxanthin and Haematococcus pluvialis on growth performance, antioxidant status and immune response of large yellow croaker Pseudosciaena crocea. Aquaculture 434: 227-232.

Lakeh, A.A.B., Ahmadi, M.R., Safi, S., Ytrestøy, T., Bjerkeng, B. 2010. Growth performance, mortality and carotenoid pigmentation of fry offspring as affected by dietary supplementation of astaxanthin to female rainbow trout (Oncorhynchus mykiss) broodstock. Journal of Applied Ichthyology 26(1): 35-39.

Kalinowski, C.T., Robaina, L.E., Izquierdo, M.S. 2011. Effect of dietary astaxanthin on the growth performance, lipid composition and post-mortem skin colouration of red porgy Pagrus pagrus. Aquaculture International 19(5): 811-823

Kidd, P. 2011. Astaxanthin, cell membrane nutrient with diverse clinical benefits and anti-aging potential. Altern Med Rev 16(4): 355-64..

Lim, C. 1989. Utilization of plant protein by warm water fish. Proceedings of the world congress on vegetable protein utilization in human foods and animal feedstuffs. American Oil Chemists Society, Illinois: 245-251.

Maoka, T. 2011. Carotenoids in Marine Animals. Marine Drugs 9(2):278-93

Pham, M.A., Byun, H.G., Kim, K.D., Lee, S.M. 2014. Effects of dietary carotenoid source and level on growth, skin pigmentation, antioxidant activity and chemical composition of juvenile olive flounder Paralichthys olivaceus. Aquaculture 431: 65-72

Ranga, R.A., Baskaran, V., Saradaa, R., Ravishankarad, G.A. 2013. In vivo bioavailability and antioxidant activity of carotenoids from microalgal biomass - A repeated dose study. Food Research International 54(1), November 2013, Pages 711-717

Ranga, R.A., Raghunath Reddy, R.L., Baskaran, V., Sarada, R., Ravishankar, G.A. 2010. Characterization of microalgal carotenoids by mass spectrometry and their bioavailability and antioxidant properties elucidated in rat model. Journal of Agricultural and Food Chemistry 58(15): 85538559.

Rehulka, J., Zak, J. 1986. Testing the effect of canthaxanthin in dry pellets on the output and some condition and physiological characteristics of market rainbow trout Salmo gairdneri R... Papers of R.I.F.H. Vodn`any 15: 79 90.

Sarada, R., Ranga R.A., Sandesh, B.K., Dayananda, C., Anila, N., Chauhan, V.S., Ravishankar, G.A. 2010. Influence of different culture conditions on yield of biomass and value added products in microalgae. Dyn. Biochem. 
Proc. Biotechnol. Mol. Biol. 2012, 6, 77-85.

Sadekarpawar, S. \& Parikh, P. 2013. Gonadosomatic and hepatosomatic indices of freshwater fish Oreochromis mossambicus in response to a plant nutrient. World J. Zool 8(1): 110-118.

Scabini, V., Fernandez-Palacios, H., L. Robaina, T. Kalinowski., M.S. Izquierdo. 2010. Reproductive performance of gilthead seabream (Sparus aurata L., 1758) fed two combined levels of carotenoids from paprika oleoresin and essential fatty acids. Aquacult. Nutr., 17: 304-312.

Shapoori, M., Ghiasvand, Z., Jamili, S. 2012. The study of synthetic and natural pigments on the colour of the Albino Oscar. International Journal of Marine Science and Engineering 2(3): 203206 .

Sheikhzadeh, N., Tayefi-Nasrabadi, H., Oushani, A.K., Enferadi, M.H. 2012. Effects of Haematococcus pluvialis supplementation on antioxidant system and metabolism in rainbow trout (Oncorhynchus mykiss). Fish Physiology and Biochemistry 38: 413419.

Tizkar, B., Soudagar, M., Bahmani, M., Hosseini, S.A., Chamani, M. 2013. The effects of dietary supplementation of astaxanthin and $\beta$-caroten on the reproductive performance and egg quality of female goldfish (Carassius auratus). Caspian Journal of Environmental Sciences 11(2): 217231

Tominaga, K., Hongo, N., Karato, M., Yamashita, E. 2012. Cosmetic benefits of astaxanthin on humans subjects. Acta Biochim Pol 59(1): 43-47.

Tukmechi, A., Rahmati, H.R., Manaffar, R., Sheikhzadeh, N. 2011. Dietary administration of betamercaptoethanol treated Saccharomyces cervisiae enhanced the growth, innate immune response and disease. Fish and Shellfish Immunology 30: 923-928.

Wang, H., Dai, A., Liu, F., Guan, Y. 2015. Effects of dietary astaxanthin on the immune response, resistance to white spot syndrome virus and transcription of antioxidant enzyme genes in Pacific white shrimp Litopenaeus vannamei. Iranian Journal of Fisheries Sciences 14(3): 699-718.

Yamashita, E. 2009. Eye fatigue (asthenopia) relief by astaxanthin. Anti-Aging Therap 11: 361-379.

Yamashita E. 2011. Astaxanthin and sports performance (in Japanese). FOOD Style 21 15(3): 36-38.

Yi, X., Xu, W., Zhou, H., Zhang, Y., Luo, Y., Zhang, W., Mai, K. 2014. Effects of dietary astaxanthin and xanthophylls on the growth and skin pigmentation of large yellow croaker Larimichthys croceus. Aquaculture 433:377-83.

Yuan, J.P., Peng, J., Yin, K., Wang, J.H. 2010. Potential health-promoting effects of astaxanthin: A high-value carotenoid mostly from microalgae. Mol Nutr Food Res 55(1): 150-165.

Zhang, J., Li, X., Leng, X., Zhang, C., Han, Z., Zhang, F. 2012. Effects of dietary astaxanthins on pigmentation of flesh and tissue antioxidation of rainbow trout (Oncorhynchus mykiss). Aquac Int 21 (3):579-89. 